Полич С. Б.

ЦИФРОВАЯ ИНФОРМАЦИА И ПРАВОСУБВЕКТНОСТЬ ФИЗИЧЕСКОГО ЛИЦА

\title{
Polich S. B. DIGITAL INFORMATION AND LEGAL PERSONALITY OF AN INDIVIDUAL
}

\begin{abstract}
Цифровая информация выступает важнейшим элементом реальной действительности, цифровая информация «способна» существовать вне ее биологических носителей - физических лиц. Современное существование физического лица в реальном обществе уже невозможно без цифровой информации, которая «помогает» покорять виртуальное пространство, делая его более открытым и доступным для совершения фактических и юридических действий. Соответственно предполагается, что цифровая информация - это не что иное как элемент правосубъектности физического лица.

Ключевые слова: цифровая информация, физические лица как носители цифровой информации, цифровая информация как элемент правосубъектности физического лица, виртуальные лица.

Digital information is the most important element of reality, digital information is "capable" of existing outside its biological carriers - individuals. The modern existence of an individual in a real society is no longer possible without digital information, which "helps" to conquer the virtual space, making it more open and accessible for actual and legal actions. Accordingly, it is assumed that digital information is nothing more than an element of the legal personality of an individual.

Keywords: digital information, individuals as carriers of digital information, digital information as an element of the legal personality of an individual, virtual persons.
\end{abstract}

Бурно развивающиеся информационные технологии «возвели» цифровую информацию в ранг социального феномена.

Общеизвестно, что наиболее «распространенными» субъектами информационных отношений выступают физические лица.

Цифровая информация - это не что иное как структурный компонент информации как социального явления. В состав цифровой информации включаются сведения не только об объектах частного права, но и сведения о субъектах частного права.

Информационная телекоммуникационная сеть «Интернет» «набирает обороты», и, постепенно становится реальным «конкурентом» материальному миру.

Цифровая информация как структурный компонент глобального информационного пространства, аккумулирующегося, в том числе, в сети «Интернет», также постепенно, но одновременно последо- вательно становится «оторванной» от реального материального пространства.

Основная проблема правового регулирования цифровой информации состоит в том, что на настоящем этапе развития не поддаются какому-либо не только правовому, но даже социальному регулированию, скажем, большие данные (big date), заполнившие информационное пространство.

Позволим, обратиться к высказываниям Н. Винера на понимание информации как социального (общественного) явления.

Информация - это обозначение содержания, полученного из внешнего мира В процессе нашего приспособления к нему и приспосабливания к нему наших чувств. Процесс получения и использования информации является процессом нашего приспособления к случайностям внешней среды и нашей жизнедеятельности в этой внешней среде. Потребности и сложность современной жизни предъявляют большие, чем когда-либо раньше, 
требования к этому процессу информации и наша пресса, наши музеи, наши научные лаборатории, университеты, библиотеки и учебники должны удовлетворить потребности этого процесса, так как в противном случае они не выполнят своего назначения.

Действенно жить - это значит жить, располагая правильной информацией. Таким образом, сообщение и управление точно также связаны с самой сущностью человеческого существования, как и с жизнью человека в обществе [1,21-22].

При определении информации Hoeren Т. пишет, что в конечном итоге информация «есть всякое получение знаний (сведений) о каждом реальном и нереальном объекте материального мира» [2, с. 1].

Виртуальные лица постепенно вовлекаются в современный имущественный и неимущественный оборот, что свидетельствует об объективной необходимости правового регулирования общественных отношений с их участием.

«Виртуальное лицо», под которым предлагается понимать «сетевую проекцию» реального физического лица либо «придуманный» физическим лицом вымышленный персонаж, функционирующий лишь в виртуальном пространстве. Подобных проекций и персонажей у одного физического лица может быть бесчисленное множество....

Современные тенденции развития российского общества свидетельствуют о серьезном «обособлении» субъектов частных прав от объектов частных прав, что обусловлено тенденцией повсеместной индивидуализации человеческого пространства.

Индивидуализация человеческого пространства свидетельствует о том, что важную юридическую ценность для реальных субъектов (физических лиц) и виртуальных субъектов (электронных проекций физических лиц) гражданских правоотношений будут иметь информационные ресурсы (в противовес материальным ресурсам).

Или, «может быть, в недалеком будущем в гражданском праве все и все будут «танцевать» вокруг «информационных продуктов» [3, с. 7].
Функционирование виртуальных лиц направлено на замещение физических лиц в общественном пространстве. В правовом пространстве виртуальные лица - это «осознанная проекция человека» или quasi-физическое лицо.

Эти общественные явления в юридическом смысле представляют собой некую «сознательную проекцию» человека, или являются quasi-физическим лицом.

На данном этапе развития общественных отношений к этим явлениям можно попробовать применять правовую форму «виртуального лица» [4, с. 676].

Правосубъектность не существующего в реальной (материальной) действительности лица может свидетельствовать о новом наполнении этой категории. Виртуальное лицо - это лицо, которое существует только в сознании иных людей, или это коллективное сознательное, а, может быть, и коллективное бессознательное?!

Представление о физическом лице формируется сквозь призму его виртуальной оболочки, которая не всегда является объективной (действительной), поскольку может искажать реальные данные физического лица.

Вместе с тем, мы наблюдаем новые способы индивидуализации субъектов гражданских правоотношений - физических лиц.

Набор кодовых данных, совокупность цифр, последовательность иных обозначений, видимо, уже в недалеком будущем, могут стать не чем иным, как элементом правосубъектности физического лица.

Или «электронные личности» постепенно заменят реальных субъектов гражданского оборота - физических лиц....

Итак, с развитием информационных технологий физические лица «обретают» правовую оболочку в виде цифровой информации.

Цифровая информация представляет собой набор сетевых данных о физическом лице, а также его «виртуальную» оболочку.

Такая цифровая информация становится de-facto элементом правосубъектности физического лица.

\section{Литература}

1.Винер Н. Кибернетика и общество. Творец и робот.- М.: Тайдекс Ко, 2003248 с. (Библиотека журнала «Экология и жизнь».

2. Hoeren T, Grunzige des Internetrechts: E-Commerce/Domains/ Urheberrecht. Munchen. Beck. 2001.265 s.

3.Полич, С.Б. Принципы в гражданском праве: учебное пособие/ С.Б. Полич. Челябинск. 2017. 28 с. 
4. Полич С.Б. Некоторые особенности правосубъектности лиц, участников гражданских и семейных отношений/ Вестник Пермского университета. Юридические науки. - 2018, № 4, С.664-684.

\section{References}

1.Viner N. Kibernetika i obshchestvo. Tvorets i robot.- M.: Taydeks Ko, 2003- 248 s. (Biblioteka zhurnala «Ekologiya i zhizn'».

2. Hoeren T, Grunzige des Internetrechts: E-Commerce/Domains/Urheberrecht. Munchen. Beck. 2001. S.265

3.Polich, S.B. Printsipy v grazhdanskom prave: uchebnoye posobiye/ S.B. Polich. Chelyabinsk. 2017. S. 28.

4. Polich S/B/ Nekotorye osobennosti pravosub*ektnosti lits - uchastnikov grazhdaskikh i semeynykh otnoshenyi \{Some Peculiar Features of Legal Personality of Persons Participating in Civil and Family Relations\}/Vestnik Permskogo universiteta. Yuridicheskie nauki - Perm University Herald Yuridikal Sciences 2018. Issue 4. P. 664-684.

полич Светлана Байрамовна, кандидат юридических наук, доцент, доцент кафедры гражданского права и гражданского судопроизводства, Южно-Уральский государственный университет. 454080, г. Челябинск, пр. Ленина, 76. E-mail: polichsb@susu.ru

POLICH Svetlana Bayramovna, Candidate of Legal Sciences, Associate Professor, Associate Professor of the Department of Civil Law and Civil Procedure, South Ural State University. 454080, Chelyabinsk, Lenin Ave., 76. E-mail: polichsb@susu.ru 